\title{
Truso in the Old English Orosius and Tczew, Poland
}

\author{
Andrew Breeze \\ University of Navarre
}

Wulfstan's description of his voyage to the Baltic is an addition to the Old English Orosius. It contains a notorious crux, as follows. Wulfstan (otherwise unknown) sailed to Truso, a trading-place near the mouth of the Vistula. Anglo-Saxonists and others have long identified Truso as somewhere on Lake Drużno, near Elbląg, Poland. But in 1985 the Polish philologist Stanisław Rospond disproved that. He regarded Truso as Tczew on the lower Vistula. Tczew (in German, Dirschau) is attested in early documents with forms (Trsow, Trssew, Treseu) that are compatible with Truso. Those for Drausensee or Lake Drużno (recorded in 1233 as Drusin) are not compatible with Truso. They start with the wrong letter and have an internal $<\mathrm{n}>$ absent from spellings of Tczew. His conclusions have nevertheless been ignored, despite their implications for English history and Polish or Viking archaeology.

Let us set the out the story in detail. In the year 891 or so, a mariner called Wulfstan made a journey to the Baltic. Wulfstan's account of his travels (surviving as an addition to the Old English Orosius) has had an unusual history. It was printed as early as 1598, when Richard Hakluyt included a translation of it in one edition of his Voyages. It is still read in Old English courses at conservative universities. Yet problems remain.

Before we consider those, readers might obtain a map of the Gdańsk region. Failing that, they should keep in their mind's eye this image. As it nears the Baltic, the Vistula divides into branches. Three of them concern us here. On the left bank of the westernmost branch is the port of Gdańsk. South-southeast of it is the town of Tczew, on the west bank of the Vistula's main channel. It is located on a headland at a major crossing-point, sixteen miles from where this channel meets the Baltic. Between Tczew and the sea was once a huge marshland, impassable on foot, making the dry ground of its site (where the 
Vistula leaves hill country to enter its delta) an obvious place for settlement. East of Tczew is the Nogat, easternmost of the Vistula's three branches. While the other two reach the Baltic directly, the Nogat flows into Zalew Wisłany, a coastal lagoon or sea known until 1945 as Frisches Haff. Three miles east of the Nogat is the town of Elblagg, five miles inland from Zalew Wisłany. It is situated on the right bank of the River Elblagg, which passes through Lake Drużno before reaching the town, and then enters Zalew Wisłany via its own estuary. Sixty miles east of Elbląg, in territory of the Russian Federation, is Kaliningrad, formerly Königsberg, close to Zalew Wisłany's eastern limit.

Such is the Vistula's delta now. In the ninth century (as we shall see), there were major differences. These points in mind, we turn to Estmere in Bosworth's dictionary, which offers this passage and translation:

Seo Wisle lip ut of Weonodlande, and lip in Estmere; and se Estmere is huru fiftene mila brad. ponne cymep Ilfing eastan in Estmere of ðxm mere, ðe Truso standep in staðe.

'The Vistula flows out of Weonodland and runs into the Frische Haff [Estmere]; and the Frische Haff is, at least, fifteen miles broad. Then the Elbing comes from the east into the Frische Haff, out of the lake [Drausen] on the shore of which Truso stands.'

With the above is commentary on Estmere as Frisches Haff, a lake "about sixty miles long, and from six to fifteen broad" which is "separated by a chain of sandbanks from the Baltic Sea”. For this information the compiler thanks a Dr Bell, "who matriculated at the University of Königsberg, near the west end of the Haff” (Bosworth 1898: 259). If, however, Dr Bell thought that Königsberg was by the west end of Frisches Haff and not its east, he can have noticed little of his surroundings.

Now for some of the forms given by Wulfstan. His Weonodland is the territory of the Wends, a people who "pressed forward into the lands between the Elbe and the Vistula vacated by the Germans, where Wulfstan found them in the ninth century" (Chambers 1912: 209). Wyatt took things further, citing Henry Sweet's identification in 1883 of Truso as Drausen. Knowing of no such town, he considered it "clear that 'the lake on whose shore Truso stands' is Drausen See between E. and W. Prussia"; the mysterious town of Truso may thus have been Elbing/Elbląg, Drausensee perhaps once having "extended to its walls". For the phrase after that on the Ilfing (or River Elbląg), which the Vistula "wickedly deprived of its name", Wyatt (1919: 210) suggested that in Wulfstan's day the "Ilfing was then a tributary of Wisle". 
So Wyatt in 1919. Forty-two years later, Labuda (1961: 71, 82, 302) surveyed the question with reference to Prussian and other scholarship, beginning with Ferdinand Neumann's analysis of 1854. Labuda, while assuming that the "passage is clear" (opis jest jasny) and required no emendation, admitted that the location of Truso was unknown to us (jest nam nieznane), although it must have been near Lake Drużno, formerly bigger and with shores beyond its present ones. In a résumé, he restated belief in Truso as a port "auprès de la cité médiévale d'Elbląg". Soon after, Jacek Fisiak (1962: 78-89) published on the question (at Łódź) his first academic paper. It has been noticed in Poland but not beyond.

In English, remarks of the following kind are typical. A discussion of overseas trade includes mention of how Wulfstan ("probably an Englishman") traded with "a port near the modern Danzig" (Loyn 1962: 90). Elsewhere is reference to Truso "at the mouth of the Vistula" (Kirby 1967: 269). Dorothy Whitelock (1967: 230, 231) echoed Henry Sweet on Truso as "a lost town, possibly Elbing, on the Drausen See, which preserves the name", with Estmere as Frisches Haff and Ilfing as the River Elbing.

A specialist history has more information. Wulfstan (“a Norwegian?") sailed to Zalew Wisłany and to Truso, taken as Elbląg, if without confidence; for "to the present no true town has been found and excavated. Instead there have been finds of Norse weapons, and there is a large Viking Age cemetery near the modern town's railway station" (Jones 1968: 110, 247). Hence Stenton's (1971: 274) description of Truso merely as a "port" near "the mouth of the Vistula". Even in Poland, Truso was still regarded as a port "in the vicinity of present-day Elblagg" (Zins 1974: 9). Dorothy Whitelock, seeing "no reason to deny English nationality" (1974: 124) to Wulfstan, whose name was English, merely referred to Frisches Haff without further details.

A full translation of the entire passage followed (Swanton 1975: 36):

The Vistula is a very great river, and it separates Wit-land and Wend-land; and Wit-land belongs to the Ests; and the Vistula flows out of Wend-land and flows into the Zalew Wisłany; and the Zalew Wisłany is at least fifteen miles broad. Then the Elbing comes from the east into the Zalew Wisłany from the lake on whose shore stands Truso; and there come out together into the Zalew Wisłany: the Elbing from the east out of Estonia, and the Vistula from the south out of Wend-land. And then the Vistula gives its name to the Elbing and flows west and north from that lake into the sea; therefore it is called Vistula-mouth. 
A remark of Witold Ostrowski (1976: 209-231), on how Wulfstan's text has a "geopolitical" aspect, reminds one how (after Danish wars) Alfred had military reasons to inform himself on Baltic topography. But Ostrowski followed Labuda for Truso as near Elblag. An official history of Poland has mention of Wulfstan's visit to Truso, "an active buying and selling centre" near modern Elbląg (Gieysztor 1979: 23-141).

In 1980 appeared Janet Bately's edition (1980: 198) of this text, where she showed herself less certain than earlier writers. She quoted Foote \& Wilson for "the lake on the shore of which Truso stands" as Lake Drużno (formerly Drausensee), but also their comment on how Truso itself could be "anywhere between Danzig and Kaliningrad" and how identification with Elbląg is "inconclusive". She further noted the difficulties of its initial $<t>$, relating it to questions of dictation, and cited a 1977 paper by E. G. Stanley on how the Ilfing or Elbląg was "wickedly deprived of its name" by the Vistula, with the suggestion that the Ilfing (not Vistula) may here be the subject. Some of this is illogical. If Truso was near Gdańsk or Kaliningrad, it was not by Lake Drużno; as regards spelling, the question of dictation appears irrelevant, for the passage is not by the translator (surely a Cornishman, despite what is claimed) dictating to a West Saxon scribe, as Janet Bately well knows.

In another official history, Labuda (1980: 33-217) again referred to Truso as "in the Nogat delta" ( $w$ delcie Nogatu). From the same year come maps of the region in the ninth century and in about 1300, with the first showing Truso as on the site of Elblag, north of which the Nogat flows into a Lake Drużno nine times its present size (Zbierski \& Jasinski 1980: 69-336). So a branch of the Vistula would have joined the River Elblagg, even though the book's main text offers no evidence to locate Truso at Elbląg. There is a further implication. Truso was a trading city of international fame. Yet nothing in the archaeological and historical record puts it at Elblag. In contrast is Tczew, situated on a hill at the last point before the Vistula reached its delta, once a vast fenland. The volume on Gdańsk here cited has a wealth of reference to Tczew's past from prehistoric and Roman times onwards. Why this silence on Truso, when we have an abundance of material on ancient and medieval Tczew? Before offering a reason, we note how Keynes \& Lapidge (1983: 258) remarked that it is "not certain" that Wulfstan addressed King Alfred, unlike the Arctic voyager Ohthere, whose account come before his.

For all commentators, 1985 was a year of an unnoticed revolution accomplished by Stanisław Rospond (1985: 395). He was a great scholar, a philologist and historian of the Polish language (especially in Silesia), whose 
work should be better known than it is. His observations on Truso, in a long entry on Tczew, are epoch-making. He said this. The site, on a headland above the Vistula, was inhabited in the Bronze Age and Roman period; in the early middle ages it lay on a great trade-route for amber. Rospond regarded Tczew as probably the Truso of Wulfstan's account, tending to reject a connection with Drausensee or Lake Drużno (recorded in 1233 as Drusin), thirty miles to the east. Tczew (in German, Dirschau) is attested in 1193 as Trsow, in 1263 as Trssew, in 1277 as Treseu; the form can be linked with early Polish treść 'reed, rush, bulrush' (appropriate for a site above marshes). Tczew, to this day an important railway junction, has bridges across the Vistula giving it vital strategic significance in both world wars (leading to its devastation in the latter).

Once Truso is taken as Tczew, many problems vanish. Wulfstan's Truso is readily aligned with the Trsow of 1193 and other forms. A connection with Lake Drużno can be ruled out in the light of Drusin from 1243. Initial $<\mathrm{d}>$ and final $<\mathrm{n}>$ cannot be reconciled with Truso. Yet maps provided with a textbook still show Truso at Elbląg; another map, of the Vistula's delta in about 1300, demonstrates how its channels and sea-outlets have changed greatly. Both show as well Tczew's site on high ground by the Vistula's main stream (Samsonowicz 1985: 11). Janet Bately (1991: 71-87) thereafter referred to Wulfstan as reaching "the mouth of the Vistula". Else Roesdahl (1991: 280) thinks that Truso "presumably lay at Elbing". This is at least better than a statement on Wulfstan's voyage "to Estonia", as if he approached Finland (Smyth 1995: 539). Professor Stanley (1996: 258-259), adding a German reference of 1764 to others on Wulfstan's voyage, explained "out of the lake [mere] on the shore of which Truso stands" as "from the Haff on the shore of which Truso stands"; which puts Truso on Zalew Wisłany and not on inland waters.

A handbook has a passing allusion to Wulfstan's "expanded descriptions" on what he saw (Sheppard 1999: 346-347). Elsewhere is mention of Ohthere as evidence for the translation of Orosius as "prepared in collaboration" with Alfred (Stanton 2008: 116-125). Hiatt (2010: 649-676) quotes research of 1984 by Christina Fell and 2002 by Mathew Townend for Wulfstan as an Anglian, not a West Saxon. Despite that, Professor Magennis (2011: 61) thinks him "perhaps a Dane". Professor Godden (2016: 345), translating the Old English Orosius into Modern English, now thinks Truso perhaps a "significant trading town on a lake or inland separated from the Baltic itself by an area of sandbank". Here "significant trading town" is correct. The "lake or inland sea" is not. Professor Godden, basing his ideas on Sweet's erroneous identification, here as elsewhere displays misplaced assurance. 
Our conclusions are clear. Tczew (the Kingdom of Prussia's Dirscbau) appears in medieval documents as Trsow, Trssew, Treseu. Rospond can be vindicated on taking it as Wulfstan's Truso. The town, on the main channel of the Vistula, has been a communications and trading centre from the Bronze Age to the present, although Gdańsk eclipsed it in the later middle ages, when changes in the Vistula's course gave Gdańsk access to its main channel. Truso being Tczew, the details of Wulfstan's geography can now be deduced from maps of the Vistula's delta already mentioned (where historical topographers should not be misled by previous translations of Orosius). Anglo-Saxonists may now co-operate with Tczew's archaeologists on their town's illustrious past, when it had contacts even with England, where Wulfstan perhaps showed Tczew amber to Alfred and his court. Polish Anglicists may similarly feel pride in Tczew as a town in Poland known in England as early as the ninth century. As for Sweet's views on Lake Drużno, they can be dismissed. They are an error repeated too long in books on Alfred and his age.

Since the above was submitted for publication, the writer has received a referee's report providing important updating on archaeology. It casts new light on Wulfstan's account of his voyage, which (it may be said again) is an addition to the translation. It is an interpolation within the main text, which was seemingly dictated by a Cornishman to a West Saxon scribe. (The pronunciation of Truso hence owes nothing to any British translator.)

The referee drew attention to fundamental work by Polish archaeologists, the results of their excavations being summed up in two recent books. The former (on which this writer thanks the referee) concerns Tczew and its early medieval archaeology (Kleingärtner 2014). It should be used by all researchers concerned with the genuine Truso. The latter volume is more curious. It shows how Rospond's work has had no impact, for one of its contributors declares that "the remains of the town of Truso were finally successfully identified in 1982 by the Polish archaeologist Marek Jagodziński", before giving details of his excavations at a site by Lake Drużno (Gardela 2015: 213-214).

The upshort of these recent books is clear. Rospond's case is still ignored, even in Poland. Those concerned with the archaeology of the Vikings on Polish soil are therefore strongly recommended to consult the studies by Kleingärtner and Gardela cited here. As soon as that is done, progress for students of early English-Viking-Polish relations is bound to come. 


\section{References}

Bately, J. ed. 1980: The Old English Orosius. Oxford, Oxford University Press.

Bately, J. 1991: The Nature of Old English Prose. In M. Godden \& M. Lapidge eds. The Cambridge Companion to Old English Literature. Cambridge, Cambridge University Press: 71-87.

Bosworth, J. 1898: An Anglo-Saxon Dictionary. Oxford, Oxford University Press.

Chambers, R. W. 1912: Widsith: A Study in Old English Heroic Legend. Cambridge, Cambridge University Press.

Gardela, L. 2015: Vikings in Poland: A Critical Overview. In M. H. Ericksen, U. Pedersen, B. Rundberget, I. Axelsen \& H. Berg eds. Viking Worlds. Oxford, Oxbow Books: 213-234.

Gieysztor, A. 1979: Medieval Poland. In S. Kieniewicz ed. History of Poland. 2nd ed. Warszawa, Państwowe Wydawnictwo Naukowe: 23-141.

Fisiak, J. 1962: Emendacje polskiego przekładu tekstów staroangielskich. Rozprawy Komisji Jezzykowej ŁTN 8: 78-89.

Godden, M. ed. 2016: The Old English History of the World. Cambridge \& Massachusetts, Harvard University Press.

Hiatt, A. 2010: Maps and Margins. In E. Treharne \& G. Walker eds. The Oxford Handbook of Medieval Literature in English. Oxford, Oxford University Press: 649676.

Jones, G. 1968: A History of the Vikings. London, Oxford University Press.

Keynes, S. \& M. Lapidge 1983: Alfred the Great. Harmondsworth, Penguin.

Kirby, D. P. 1967: The Making of Early England. London, Batsford.

Kleingärtner, S. 2014: Die frühe Phase der Urbanisierung an der südlichen Ostseeküste im ersten nachchristlichen Jahrtausend. Neumünster, Wachholtz Verlaf.

Labuda, G. 1961: Źródła, sagi i legendy do najdawniejszych dziejów Polski. Warszawa, Panstwowe Wydawnictwo Naukowe.

Labuda, G. 1980: Diplomacja Polska wczesnego feudalizmu (wiek X - 1306r.). In M. Biskup ed. Historia diplomacji Polskiej. Warszawa, Państwowe Wydawnictwo Naukowe: 33-217.

Loyn, H. R. 1962: Anglo-Saxon England and the Norman Conquest. London, Longman.

Magennis, H. 2011: The Cambridge Introduction to Anglo-Saxon Literature. Cambridge, Cambridge University Press.

Ostrowski, W. 1976: Literatura staropolska a literatura angielska. In T. Michalłowska \& J. Śląski eds. Literatura staropolska w kontekscie europejskim. Wrocław, Zakład Narodowy imięnia Ossolińskich: 209-231.

Roesdahl, E. 1991: The Vikings. London, Allen Lane.

Rospond, S. 1984: Stownik etymologiczny miast i gmin PRL. Wrocław, Zakład Narodowy im. Ossolińskich. 
Samsonowicz, H. 1990: Historia Polski do roku 1795. 5th ed. Warszawa, Wydawnictwa Szkolne i Pedagogiczne.

Sheppard, A. 1999: Orosius. In M. Lapidge, J. Blair, S. Keynes \& D. Scragg eds. The Blackwell Encyclopedia of Anglo-Saxon England. Oxford, Blackwell: 346-347.

Stanley, E. G. 1996: How the Elbing Deprives the Vistula of its Name: An Unnoticed Reference. Notes and Queries 241: 258-259.

Stanton, R. 2008: King Alfred. In R. Ellis ed. The Oxford History of Literary Translation in English: to 1500. Oxford, Oxford University Press: 116-125.

Stenton, F. M. 1971: Anglo-Saxon England. 3rd ed. Oxford, Clarendon Press. Smyth, A. P. 1995: King Alfred the Great. Oxford, Oxford University Press.

Swanton, M. J. trans. 1975: Anglo-Saxon Prose. London, Dent.

Whitelock, D. ed. 1967: Sweet's Anglo-Saxon Reader. 15th ed. Oxford, Clarendon Press. Whitelock, D. 1974: The Beginnings of English Society. Rev. ed. Harmondsworth, Penguin.

Wyatt, A. J. ed. 1919: An Anglo-Saxon Reader. Cambridge, Cambridge University Press.

Zbierski, A. \& J. Kazimierz. 1980: Gdańsk w okresie panowania królow polskich i ksiązat pomorskich (od IX w. do XIII w.). In E. Cieslak ed. Historia Gdańska: Tom I do roku 1454. Gdańsk, Wydawnictwo Morksie: 69-336.

Zins, H. 1974: Polska w oczach Anglików. Warszawa, Państwowy Instytut Wydawniczy.

Author's address

Departamento de Filología

Universidad de Navarra

Pamplona 31009 (Spain)

received: 16 March 2021

e-mail: abreeze@unav.es revised version accepted: 12 April 2021 